\title{
DETEKSI DINI KANKER SERVIKS DAN PAYUDARA DENGAN PEMERIKSAAN IVA SERTA SADANIS DI PERUMAHAN KARTIKA SEJAHTERA KELURAHAN SASAK PANJANG KECAMATAN TAJUR HALANG KABUPATEN BOGOR JAWA BARAT
}

\author{
Dewi Novitasari Suhaid ${ }^{1}$, Dyah Woro Kartiko Kusumo Wardani ${ }^{2 *}$, Baharika \\ Suci Dwi Aningsih ${ }^{3}$, Eviyani Margaretha Manungkalit ${ }^{4}$, Margaretha \\ Kusmiyanti ${ }^{5}$ \\ ${ }^{1-5}$ STIK Sint Carolus \\ Email Korespondensi: dyahworo0@gmail.com \\ Disubmit: 05 Juli 2021 \\ $\begin{array}{rr}\text { Diterima: } 08 \text { Juli } 2021 & \text { Diterbit } \\ \text { DOI: https://doi.org/10.33024/jkpm.v5i2.4630 }\end{array}$
}

\begin{abstract}
ABSTRAK
Kanker merupakan masalah kesehatan yang penting bagi wanita di seluruh dunia Penyakit kanker pada perempuan terbanyak pertama payudara diikuti serviks. Kejadian kanker payudara sebanyak 42,1 per 100.000 penduduk sedangkan kanker leher rahim 23,4 kejadian per 100.000 penduduk, dimana 75\%nya pernah berhubungan seksual. Kanker ini telah menyerang lebih dari 1,4 juta wanita di seluruh dunia. Di wilayah Bogor penderita kanker meningkat dari 316 pada tahun 2018 menjadi 353 pada tahun 2019. Sejauh ini tercatat bahwa diantaranya 196 penderita kanker payudara dan 43 penderita kanker serviks. WHO menyatakan 43\% penyakit kanker serviks dan payudara dapat dicegah dengan menempuh gaya hidup sehat dan $1 / 3$ dari keseluruhan kasus tersebut dapat disembuhkan jika gejalanya diketahui lebih dini dengan melakukan pemeriksaan IVA (Inspeksi Visual Asam Acetat) /pap smear dan SADANIS (pemeriksaan payudara klinis). Tujuan setelah penyuluhan timbul kesadaran untuk memeriksakan diri dan terdeteksi secara dini kanker serviks dan payudara. Adapun kegiatan yang dilakukan berupa penyuluhan dan pemeriksaan IVA serta SADANIS. Ibu-ibu yang mendapatkan penyuluhan akhirnya mau memeriksakan diri saat itu pada tempat yang sudah disediakan sehingga pasca kegiatan dapat terdeteksi secara dini kanker serviks dan payudara di Perumahan Kartika Sejahtera Kelurahan Sasak Panjang Kecamatan Tajur Halang Kabupaten Bogor Jawa Barat.
\end{abstract}

Kata Kunci: Kanker Serviks, Kanker Payudara, IVA, SADANIS

\begin{abstract}
Cancer is an important health problem for women worldwide. Cancer is the most common in women, followed by the breast, followed by the cervix. The incidence of breast cancer is 42.1 per 100,000 population, while cervical cancer is 23.4 events per 100,000 population, of which $75 \%$ have had sexual intercourse. This cancer has attacked more than 1.4 million women worldwide. In the Bogor area, cancer patients increased from 316 in 2018 to 353 in 2019. So far, it has been recorded that among them are 196 breast cancer patients and 43 cervical cancer sufferers. WHO states that $43 \%$ of cervical and breast cancers can be prevented by adopting a healthy lifestyle and $1 / 3$ of all cases can be cured if the symptoms are detected early by conducting an IVA (Visual Inspection of
\end{abstract}


Acetic Acid) / pap smear and SADANIS (clinical breast examination). The goal after the counseling is to raise awareness for self-examination and early detection of cervical and breast cancer. The activities carried out in the form of counseling and examination of IVA and SADANIS. The mothers who received the counseling finally wanted to check themselves at the place provided so that after the activity, cervical and breast cancer could be detected early in Perumahan Kartika Sejahtera, Sasak Panjang Village, Tajur Halang District, Bogor Regency, West Java.

Keywords: Cervical Cancer, Breast Cancer, IVA, SADANIS

\section{PENDAHULUAN}

Penyakit kanker merupakan masalah kesehatan yang penting bagi wanita di seluruh dunia terutama di negara berkembang seperti Indonesia. kejadian kanker yang memiliki kontribusi tertinggi pada perempuan Indonesia dalah serviks dan kanker payudara. Kejadian ini meningkat karena minimnya tindakan penapisan efektif yang dilakukan agar keadaan prakanker ataupun kejadian kanker stadium dini terdeteksi. (Kemenkes, 2019).

Kanker serviks merupakan keganasan yang tejadi pada leher rahim (serviks) dan disebabkan oleh infeksi human papilloma virus (HPV).Berdasarkan International Agency for Research on Cancer (IARC), kanker serviks menempati urutan ke dari seluruh kanker pada perempuan di dunia dengan insidensi 6,5\% dan jumlah kematian 7,7\%. Sedangkan kanker payudara menduduki peringkat pertama dengan insidensi $24,5 \%$ dan jumlah kematian 15,5\% (WHO, 2020). Insidensi kanker pada perempuan Indonesia tertinggi adalah kanker payudara sebesar $30.8 \%$ kematian dengan insidensi $15,7 \%$ diikuti kanker serviks 17,2\% dengan insidensi 8\% (Globocan, 2020).

RISKESDAS tahun 2018 prevalensi kanker di Indonesia mencapai 1.79 per 1000 penduduk. Data lainnya menyebutkan bahwa prevalensi kanker di Indonesia menempati urutan ke 8 di Asia Tenggara dan peringkat ke 23 se-ASIA (Riskesdas, 2018).

Kejadian pada perempuan, kasus tertinggi adalah kanker payudara sebesar 42,1 per 100.000 penduduk dengan rata-rata kematian 17 per 100.000 . Setelah itu kanker leher rahim sebesar 23,4 per 100.000 penduduk dengan rata-rata kematian 13,9 per 100.000 penduduk. Adanya peningkatan yang signifikan terhadap kejadian kanker di Bogor menjadi salah satu permasalahan yang memerlukan perhatian khusus. WHO menyatakan 43\% penyakit kanker dapat dicegah dengan menempuh gaya hidup sehat dan 1/3 dari keseluruhan kasus tersebut dapat disembuhkan jika gejalanya diketahui lebih dini (Rasyid Ali, 2019; WHO, 2020; Kemenkes RI, 2020).

Deteksi dini kanker leher rahim merupakan terobosan inovatif dalam pembangunan kesehatan untuk mengurangi angka kematian dan kesakitan akibat kanker leher rahim. Penyintas kanker payudara dan leher rahim pada umumya terdeteksi pada stadium lanjut. Kanker leher rahim dapat ditemukan pada tahap sebelum kanker (lesi prakanker) dengan metoda IVA dan papsmear, sedangkan untuk kanker payudara dengan metode SADANIS (memeriksa payudara klinis) oleh tenaga kesehatan (Kemenkes RI, 2019). Perkembangan kejadian kanker serviks dan kanker payudara dipengaruhi rendahnya cakupan deteksi dini kanker serviks, berdasarkan fakta pada penelitian Nurlela, 2018 menyebutkan bahwa pengetahuan merupakan salah satu faktor yang mempengaruhi perilaku perempuan untuk melakukan 
pemeriksaan dini kanker serviks (Umriyaty dan Ningrum, 2017; Purnamaningrum dan Estiwidani, 2018). Hal ini sejalan dengan penelitian Apriyanti dkk, 2020 dan Tempani, 2019 yang menyatakan adanya hubungan antara pengetahuan dengan pemeriksaan kanker serviks dengan metode IVA dan SADANIS. Salah satu metode untuk meningkatkan pengetahuan wanita tentang pentingnya pemeriksaan IVA dan SADANIS adalah dengan penyuluhan (Raffie dkk, 2021).

Penelitian di Rumah Sakit Cipto Mangunkusumo menambahkan bahwa sekitar 69,4\% dari perempuan yang terdiagnosis kanker tidak pernah menjalani deteksi dini, sehingga pada saat kanker diketahui, kanker telah ditemukan pada stadium lanjut dan pengobatan sudah sangat terlambat (Susanti, 2002; Hikmati dan adriani, 2014). Deteksi dini dengan pemeriksaan IVA merupakan alternatif dari pap smear karena murah, praktis, sangat mudah untuk dilaksanakan dan peralatan sederhana serta dapat dilakukan oleh tenaga kesehatan selain dokter ginekologi. Begitupula dengan SADANIS yang merupakan salah satu cara untuk mendeteksi adanya resiko kanker payudara oleh tenaga kesehatan yang juga dapat dilakukan berbarengan ketika memeriksakan IVA. Deteksi dini kanker payudara dikatakan meminimalisasi keterlambatan pemeriksaan awal kanker payudara (Istikomah dkk, 2021; Dyanti dan Suariyanti, 2016).

Adanya peningkatan yang signifikan terhadap angka kejadian penderita kanker menjadi salah satu latar belakang dilakukan kegiatan ini. Tercatat pada tahun 2018 sebanyak 316 penderita kanker di wilayah Bogor dan pada tahun 2019 meningkat menjadi 413 menderita. Sejauh ini tercatat bahwa penderita kanker terinci dalam beberapa katagori kanker diantaranya 231 penderita mengalami kanker payudara, 50 penderita mengalami kanker serviks, 25 penderita mengalami kanker kolorektal, kanker darah 19 orang, kanker paru 15 orang, kanker nasofaring 8 orang dan kanker lainnya 57 orang (Rasyid Ali, 2019).

\section{MASALAH}

Alasan kami memilih tempat kegiatan karena di perumahan Kartika Sejahtera adalah daerah dengan penduduk yang banyak, dan berdomisili di Bogor, dimana angka kejadian kanker payudara dan serviks banyak terjadi di daerah ini. Selain itu banyak warga yang belum pernah memeriksakan serviksnya dengan IVA dan pemeriksaan payudara karena kurangnya pengetahuan tentang metode pemeriksaan SADANIS dan IVA. Tujuan dari kegiatan ini adalah pengetahuan masyarakat meningkat tentang kanker serviks dan payudara sehingga mereka tidak takut lagi memeriksakan diri.

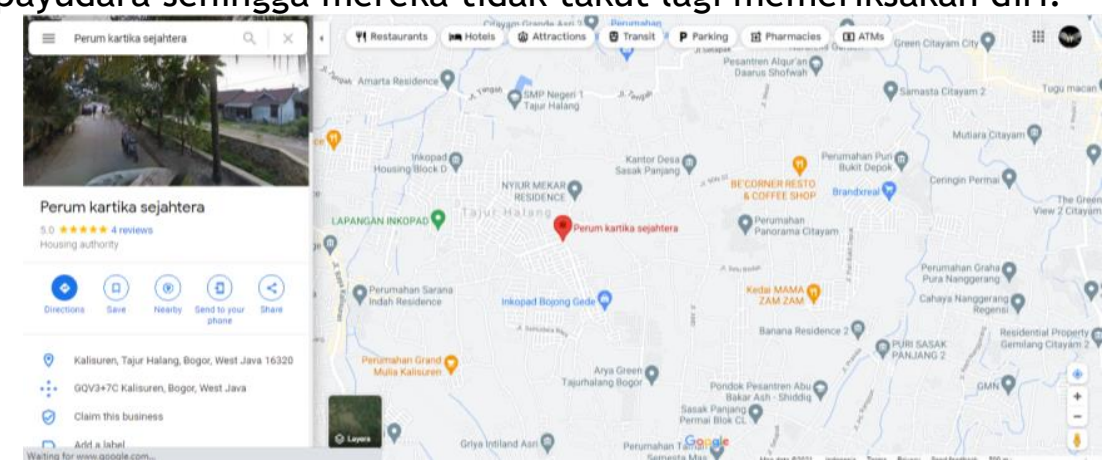

Gambar 1. Peta Lokasi Kegiatan Pengabdian Kepada Masyarakat 


\section{METODE}

\section{a. Tujuan Persiapan}

Kegiatan diawali dengan melakukan persiapan bahan dan alat yang digunakan untuk melakukan pemeriksaan IVA serta media penyampaian penyuluhan tentang kanker serviks dan kanker payudara menggunakan power point. Persiapan dilakuka pada hari Jumat 17 januari 2020 pukul 08.00-14.00 di STIK Sint Carolus Jakarta. Kegiatan dilakukan pada hari Sabtu, 18 Januari 2020 di Aula RW 006 Perumahan Kartika Sejahtera, Kelurahan Sasak Panjang, Kecamatan Tajur Halang, Kabupaten Bogor. Pada pukul 09.00 WIB dilakukan pengecekan untuk persiapan penyuluhan dan pengaturan tempat untuk pemeriksaan IVA.

\section{b. Tahap Pelaksanaan}

Acara pertama adalah sambutan yang diberikan oleh Ketua RW 006 dan dilanjutkan oleh sambutan Ketua Program Studi Kebidanan Program DIII STIK Sint Carolus Jakarta. Peserta dihadiri oleh masyarakat khususnya wanita usia subur dan lansia serta beberapa panitia ibu PKK wilayah RW 006 yang sudah terinformasi adanya kegiatan ini oleh kader setempat.

Saat pendaftaran ulang, sasaran mengisi absensi dan diukur tekanan darah serta berat badan. Lanjut pada kegiatan tersebut, sasaran dipandu untuk mengisi formulir pemeriksaan IVA pada bagian identitas dan riwayat kesehatan reproduksi.

Kemudian seluruh sasaran diberikan penyuluhan tentang deteksi dini kanker serviks dan pemutaran video tentang pemeriksaan payudara sendiri (SADARI) sebagai upaya deteksi dini kanker payudara secara mandiri yang dapat dilakukan di rumah. Kegiatan ini diakhir dengan pengisian kueioner sebagai evaluasi terhadap penyuluhan diberikan. Kuesioner ini sebagai gambaran pengetahuan mengenai kanker serviks dan payudara. Selanjutnya, secara bergiliran maka sasaran dilakukan pemeriksaan IVA di ruangan yang telah dipersiapkan. Sebelum dilakukan pemeriksaan IVA, sasaran diperiksa payudara untuk mendeteksi apakah ada benjolan atau massa pada payudara yang mengarah pada tumor/kanker payudara.

\section{c. Evaluasi}

\section{i. Struktur}

Peserta yang hadir sebanyak 31 orang di aula RW 006 Perumahan Kartika Sejahtera. Setting tempat sudah sesuai dengan rencana yang dibuat dan perlengkapan yang dibawa juga sudah memadai sesuai kebutuhan serta dipergunakan dengan baik.

Penggunaan bahasa saat berkomunikasi memberikan edukasi dalam penyuluhan sudah baik dibuktikan dari hasil evaluasi melalui kuesioner, terlihat adanya peningkatan pengetahuan terhadap kanker serviks dan kanker payudara. Dalam memberi informasi terhadap hasil pemeriksaan sudah baik, sesuai dan mudah dipahami.

ii. Proses

Pelaksanaan kegiatan dilakukan pukul 09.00-14.00 WIB. Sesuai dengan jadwal yang sudah dibuat.Acara dibagi dalam 3 sesi yaitu sesi pertama merupakan sesi pemeriksaan kesehatan dimana para peserta diminta untuk mengisi daftar hadir dan dilakukan pengkajian perameter fisiologis seperti berat badan dan tekanan darah setelah itu dilakukan pengkajian pengkajian identitas dan riwayat kesehatan reproduksi menggunaan formulir pemeriksaan IVA. Sesi kedua para peserta diberikan pendidikan kesehatan dan tanya jawab tentang deteksi dini kanker serviks dan SADANIS serta pengisian kuesioner evaluasi penyuluhan untuk mengkaji 
pemahaman peserta. Pada sesi ketiga peserta yang memenuhi kualifikasi dilakukan pemeriksaan IVA dan SADANIS. Jika ada pasien yang tidak emenuhi kualifikasi pemeriksaan IVA maka hanya dilakukan pemeriksaan SADANIS saja. Hasil pemeriksaan ditulis dalam selebar kertas dokumentasi. Setelah selesai dilakukan pemeriksaan diberikan informasi tentang hasil pemeriksaan dan konseling.

\section{HASIL DAN PEMBAHASAN}

Setelah dilakukan kegiatan dengan metode penyuluhan maka gambaran pengetahuan sasaran terkait deteksi dini kanker servik dan kanker payudara adalah sebagai berikut : pengetahuan baik sebanyak $60 \%$, pengetahuan cukup sebanyak 32,5\% dan pengetahuan kurang 7,5\%. Kategori ini diperoleh dari klasifikasi Arikunto (2019) dengan rincian pengetahuan baik berkisar antara $76-100 \%$, pengetahuan cukup $56-75 \%$ dan pengetahuan kurang $<56 \%$.

\section{Pengetahuan Wanita Usia Subur dan Lansia Terhadap Deteksi Dini Kanker Serviks dan Payudara}

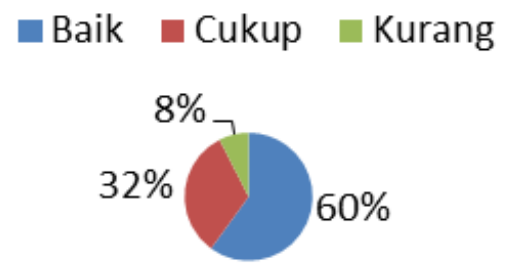

Gambar 2 Gambaran Tingkat Pengetahuan Wanita Usia Subur dan Lansia Terhadap Deteksi Dini Kanker Serviks dan Kanker Payudara.

Kegiatan selanjutnya adalah pemeriksaan IVA, hasil penapisan awal untuk deteksi payudara $100 \%$ sasaran tidak ditemukan adanya benjolan atau massa di payudara yang mengarah ke tumor/kanker payudara. Seluruh sasaran dapat mengulangi pemeriksaan SADANIS.

Hasil pemeriksaan IVA yang dilakukan pada 31 orang wanita usia subur dan lansia diantaranya 9 orang tidak dapat dinilai dengan pemeriksaan asam cuka dikarenakan 5 orang mengalami peradangan/ erosi pada porsio, 2 orang ovula nabuti, 1 orang post partum dan 1 orang terdapat polip serviks sebesar kacang merah. Dari 22 orang yang dilakukan pemeriksaan dengan diberikan asam asetat maka terdat kesimpulan penilaian 1 orang IVA positif (adanya perubahan jaringan mengarah kepada lesi pra kanker) dan 21 orang lainnya IVA negative. Dari keseluruhan sasaran yang tidak bisa dinilai dengan asam asetat dianjurkan untuk follow up ke puskesmas wilayah binaan, begitu juga dengan sasaran dengan hasil penilaian IVA positif. 


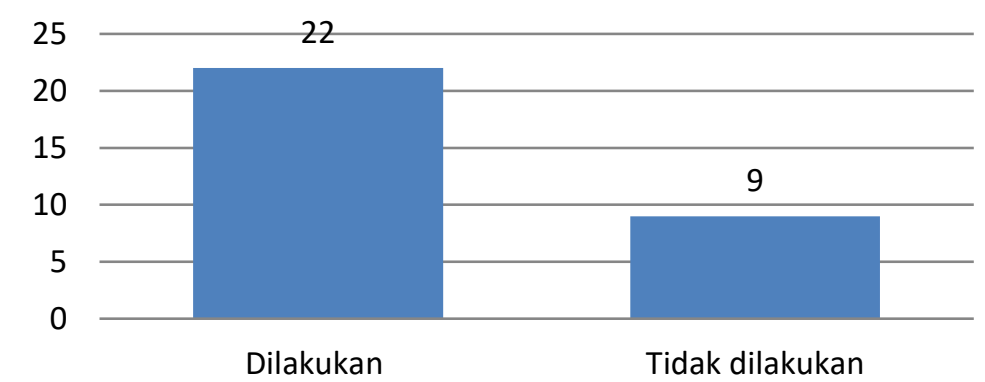

Gambar 3 Gambaran Sasaran yang Dilakukan Penilaian dengan Asam Asetat

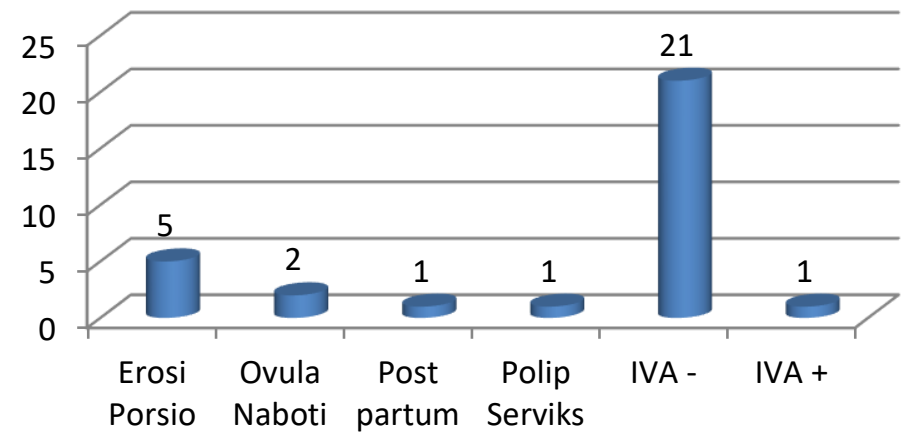

Gambar 4 Gambaran Hasil Inspekulo dan Pemeriksaan IVA

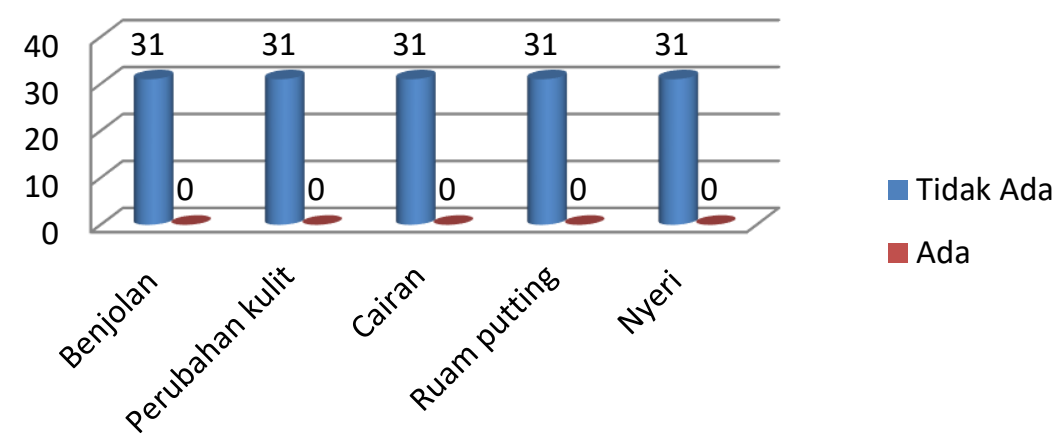

Gambar 5 Gambaran Hasil Pemeriksaan Payudara 


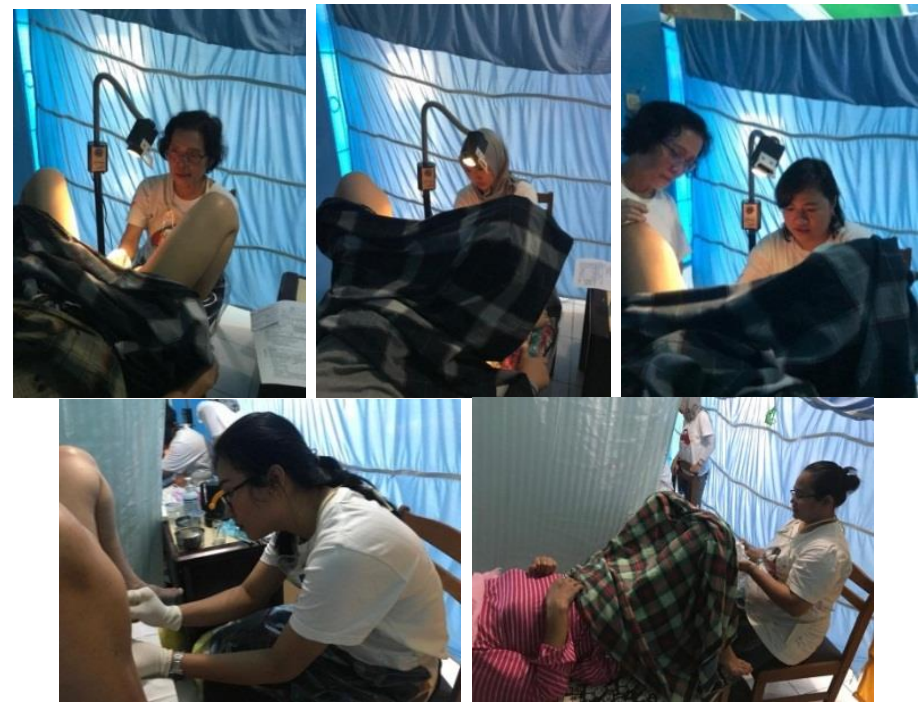

Gambar 6 Foto pemeriksaan IVA

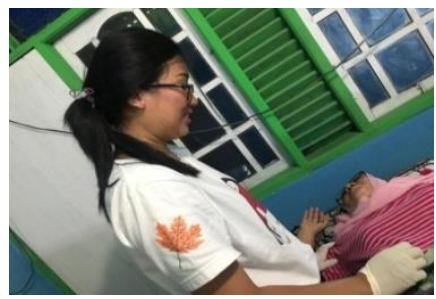

Gambar 7 Foto pemeriksaan Payudara

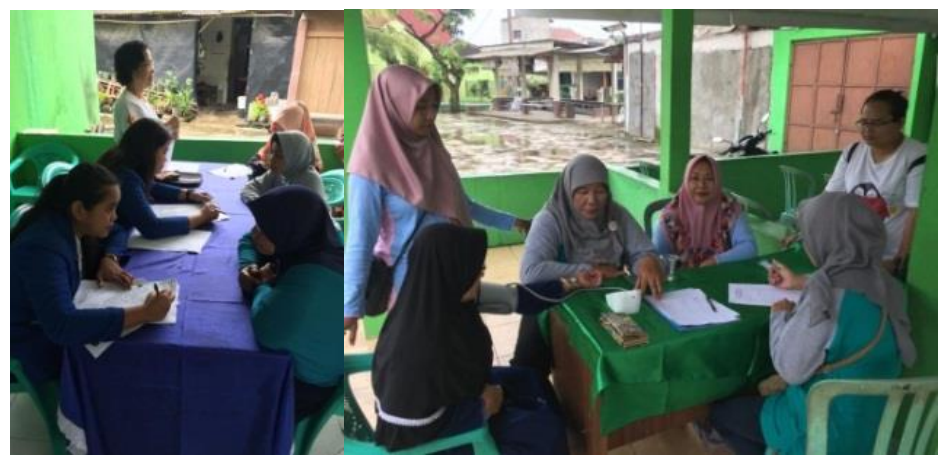

Gambar 8 Foto Anamnesa Peserta PKM

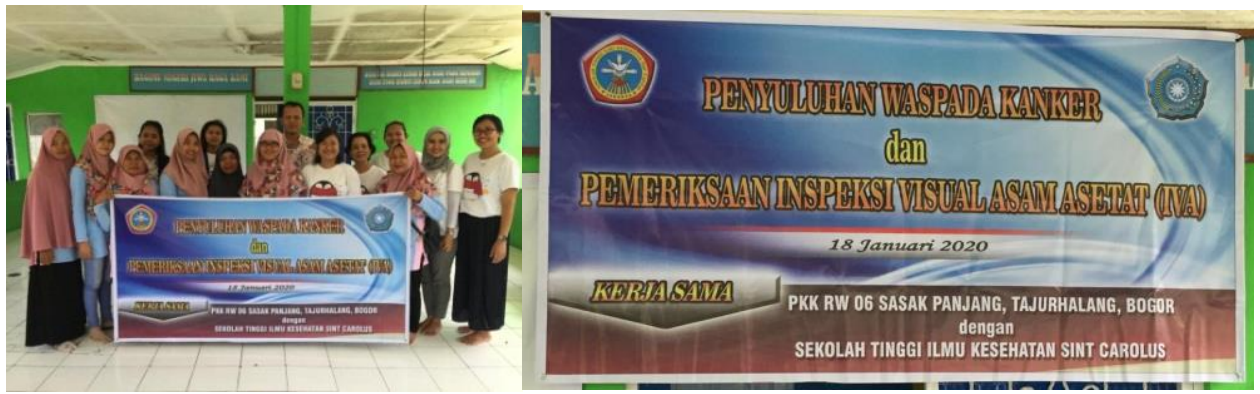

Gambar 9. Foto Panitia dan Spanduk kegiatan PKM 


\section{KESIMPULAN}

Kegiatan ini merupakan program dukungan masyarakat dan STIK Sint Carolus Program Studi Kebidanan Program Diploma dalam rangka mendukung program pembangunan pemerintah bidang kesehatan reproduksi perempuan serta meningkatnya fenomena kanker servik dan kanker payudara di dunia.

Pelaksaan kegiatan ini merupakan bagian yang tidak terpisahkan dari tridharma perguruan tinggi, terkait kewajiban dari tenaga kesehatan, dosen dan mahasiswa.

Masih terdapat persepsi negativ oleh sasaran diantaranya takut mengetahui hasil pemeriksaan, takut alat dipakai berulang kali, takut merasakan nyeri pada pemeriksaan serta malu khususnya panitia pelaksana yang belum ikut serta dalam pemeriksaan IVA.

\section{DAFTAR PUSTAKA}

Ali, Rasyid. (2019). Jumlah Penderita Kanker di Kota Bogor Naik Jadi 413 Orang. Dikutip dari Merdeka.com pada tanggal 14 Januari 2020.

https: / / www.merdeka.com/peristiwa/jumlah-penderita-kanker-di-kotabogor-naik-jadi-413-orang.html

Apriyanti, N., WiraUtami, V., Yantina, Y., \& Hermawan, D. (2020). FaktorFaktor Yang Berhubungan Dengan Pemeriksaan Ca Servik Menggunakan Metode Visual Asam Asetat (Iva). JKM (Jurnal Kebidanan Malahayati), 6(1), 37-47.

https://core.ac.uk/download/pdf/288280966.pdf

Arikunto, S. (2019). Prosedur Penelitian. Jakarta: Rineka cipta.

Dyanti, G. A. R., \& Suariyani, N. L. P. (2016). Faktor-Faktor Keterlambatan Penderita Kanker Payudara dalam Melakukan Pemeriksaan Awal ke Pelayanan Kesehatan. KEMAS: Jurnal Kesehatan Masyarakat, 11(2), 276284.

https://journal.unnes.ac.id/nju/index.php/kemas/article/view/3742

Globocan. (2020). International agency for research on cancer (IARC) 2021. Estimated number of deaths in 2020 worldwide, Indonesia, female, all ages.

https://gco.iarc.fr/today/online-analysis-

pie? $\mathrm{v}=2020 \&$ mode $=$ cancer\&mode $\_$population $=$continents\&population $=90$ 0\&populations $=900 \_360 \&$ tey $=$ total\&sex $=2 \&$ cancer $=39 \&$ type $=1 \&$ statistic $=$ $5 \&$ tprevalence $=0 \&$ tpopulation_group $=0$ \&ages_group $\% 5 \mathrm{~B} \% 5 \mathrm{D}=0$ \&ages_group $\% 5 \mathrm{~B} \% 5 \mathrm{D}=17 \& \mathrm{Enb}$ items $=7 \&$ group_cancer $=0 \&$ include_nmsc $=0$ \&include_nms c_other $=1$ \&half_pie $=0 \&$ donut $=0$ \#collapseby_country.\%20Diakses\%2029\%20Juni\%202021.

Hikmanti, A., \& Adriani, F. H. N. (2014). Analisis Faktor-Faktor Yang Mempengaruhi Keterlambatan Pengobatan Pada Wanita Penderita Kanker Payudara. In Prosiding Seminar Nasional \& Internasional. https://jurnal.unimus.ac.id/index.php/psn12012010/article/view/1253 11306

Istikomah, S. A., Widayati, W., \& Saputri, N. (2021). Pemeriksaan Inspeksi Visual Asetat (IVA) Test Pada Kelompok Ibu Aisyiyah Ranting Pringsewu. http://www.jurnal.umitra.ac.id/index.php/ANDASIH/article/view/651

Kemenkes RI. (2019). Profil Kesehatan Indonesia 2019. https://pusdatin.kemkes.go.id/resources/download/pusdatin/profilkesehatan-indonesia/Profil-Kesehatan-indonesia-2019.pdf 
Kemenkes RI. (2019). Hari Kanker Sedunia 2019. https://www.kemkes.go.id/article/view/19020100003/hari-kankersedunia-2019.html

Kemenkes RI. (2020). Penyakit Kanker di Indonesia berada pada urutan 8 di Asia Tenggara dan urutan 23 di Asia.

http://p2p.kemkes.go.id/penyakit-kanker-di-indonesia-berada-padaurutan-8-di-asia-tenggara-dan-urutan-23-di-asia/

Purnamaningrum, Y. E., \& Estiwidani, D. (2018). Determinan Perilaku Wus Dalam Melakukan Inspeksi Visual Asam Asetat (Iva) Di Wilayah Kerja Puskesmas Pangale Kabupaten Mamuju Tengah Tahun 2017 (Doctoral dissertation, Poltekkes Kemenkes Yogyakarta). http://eprints.poltekkesjogja.ac.id/1764/

Raffie, R., Noverliansyah, M. R., Nurmalasari, Y., Detty, A. U., Pratama, S. A., \& Kheru, A. (2021). Orientasi Pemeriksaan Sadari Dan Iva Di Wilayah Puskesmas Beringin Raya. Jurnal Kreativitas Pengabdian Kepada Masyarakat (PKM), 4(2), 285-290.

http://www.ejurnalmalahayati.ac.id/index.php/kreativitas/article/vie $\underline{w / 3725}$

Riskesdas. (2018). Hasil utama Riskesdas 2018. https://kesmas.kemkes.go.id/assets/upload/dir_519d41d8cd98f00/files /Hasil-riskesdas-2018_1274.pdf

Susanti NN. (2002). Analisis keterlambatan pasien kanker serviks dalam memeriksakan diri di Rumah Sakit Umum Pusat Nasional Dr. Cipto Mangunkusumo. Jakarta. (Tesis). Fakultas Kesehatan Masyarakat Universitas Indonesia.

Tempali, S. R. (2019). Analisis Hubungan Pengetahuan tentang Deteksi Dini Kanker Payudara pada Remaja Putri melalui Pemeriksaan Payudara Klinis (SADANIS). Jurnal Bidan Cerdas, 1(2), 99-104.

http://www.poltekkespalu.ac.id/jurnal/index.php/JBC/article/view/12 $\underline{7}$

Umriyaty, U., \& Ningrum, R. S. (2017). Hubungan Pengetahuan Dan Sikap Tentang Kanker Serviks Dengan Niat Melakukan Deteksi Dini Kanker Serviks Pada Wanita Usia Subur Di Kelurahan Kagok Slawi Kabupaten Tegal Tahun 2016. Siklus: Journal Research Midwifery Politeknik Tegal, 6(2). http://ejournal.poltektegal.ac.id/index.php/siklus/article/view/584

WHO. (2020). International agency for research on cancer (IARC) 2021. Estimated number of deaths in 2020 worldwide, female, all ages. https://gco.iarc.fr/today/online-analysis-

pie? $\mathrm{v}=2020 \&$ mode $=$ cancer\&mode_population $=$ continents\&population $=90$ $\underline{0 \text { \&populations }=900 \& k e y=\text { total\&sex }=2 \& \text { cancer }=39 \& \text { type }=1 \& \text { statistic }=5 \& p r}$ evalence $=0$ \& $\% 5 \mathrm{D}=17 \mathrm{Enb} \_$items $=7 \&$ \&roup_cancer $=1$ \&include_nmsc $=1$ \&include_nmsc_0 $\underline{\text { ther }=1 \text { \&half_pie }=0 \& \text { donut }=0}$ 